\title{
Identifikasi Golongan Darah O dengan Metode Absorpsi Elusi pada Sampel Darah Kering yang Terdapat pada substrat Kain Jeans dalam Waktu dan Lingkungan Berbeda [Identification of Blood Group O Using Absorption Elution Method on Dry Blood Samples Found on Jeans Fabric Substrate in Different Times and Environments]
}

\author{
Yunita Tri Utami ${ }^{1}$, Susanti Pudji Hastuti ${ }^{1} \&$ Bowo Nurcahyo ${ }^{2}$ \\ ${ }^{1)}$ Prodi Biologi, Fakultas Biologi, Universitas Kristen Satya Wacana, Salatiga; ${ }^{2)}$ Laboratorium Forensik, Unit \\ KimBio Cabang Semarang, Jawa Tengah. Email : yunitatu99@gmail.com; susanti.hastuti@uksw.edu
}

Memasukkan: Juli 2021, Diterima: September 2021

\begin{abstract}
This research aims to determine the time limit needed and the environmental conditions that provide the highest success rate in identifying dried blood samples on the fabric of stretch denim, ramie denim, black coated denim, and dry denim jeans using the elution absorption method. Also, to evaluate the effect of the fabric fabric, environmental condition, time, and interactions regarding the success rate of blood group identification. The study was conducted using 3 replications for each type of jeans fabric, which was carried out by exposing blood to a jeans fabric, leaving it in an indoor and outdoor environment for up to 336 hours (14 days), then continued by making a red blood cell suspension for comparison, and examining blood groups using the absorption-elution method. From the results obtained, it is known that the blood exposed in the jeans fabric that being placed indoor for up to 336 hours (14 days) can still be identified and has a success percentage rate of up to $100 \%$. Meanwhile, the blood exposed on the jeans fabric that was placed outdoor could no longer be identified after 264 hours (11 days). Based on the result of this study, it can be concluded that the exposure time of 366 hours (14 days) for the indoor environment can still be identified properly, while the exposure time of 264 hours (11 days) for dry blood samples in the outdoor environment can no longer be identified. The indoor environment gives a better percentage of success than the outdoor environment in identifying blood types from dry blood samples. The best types of substrates that can store blood at an exposure time of up to 336 hours (14 days) are dry denim, black coated denim, and stretch denim.
\end{abstract}

Keywords: blood group, outdoor and indoor, jeans fabric, absorption-elution

\begin{abstract}
ABSTRAK
Penelitian ini bertujuan untuk mengetahui batas waktu yang dibutuhkan dan kondisi lingkungan yang memberikan tingkat keberhasilan tertinggi dalam mengidentifikasi sampel darah kering pada substrat jeans stretch denim, denim rami, denim berlapis hitam, dan denim kering menggunakan metode absorpsi-elusi. Juga untuk mengevaluasi pengaruh substrat kain, kondisi lingkungan, waktu, dan interaksi terhadap tingkat keberhasilan identifikasi golongan darah. Penelitian dilakukan dengan menggunakan 3 kali ulangan untuk masing-masing jenis kain jeans, yang dilakukan dengan cara memaparkan darah pada substrat kain jeans dan didiamkan di di dalam dan luar ruangan selama 336 jam (14 hari), kemudian dilanjutkan dengan membuat suspensi sel eritrosit untuk darah pembanding, dan melakukan pemeriksaan golongan darah menggunakan metode absorpsi-elusi. Dari hasil yang diperoleh, diketahui bahwa darah yang terpapar pada substrat kain jeans yang diletakkan di dalam ruangan hingga 336 jam (14 hari) masih dapat teridentifikasi dan memiliki tingkat persentase keberhasilan hingga 100\%. Sementara itu, bercak darah pada substrat kain jeans yang diletakkan di luar ruangan sudah tidak dapat dikenali lagi setelah 264 jam (11 hari). Berdasarkan hasil penelitian ini dapat disimpulkan bahwa waktu pemaparan 366 jam (14 hari) untuk lingkungan didalam ruangan masih dapat diidentifikasi dengan baik, sedangkan waktu pemaparan 264 jam (11 hari) untuk sampel darah kering di lingkungan luar ruangan tidak dapat lagi diidentifikasi. Lingkungan di dalam ruangan memberikan persentase keberhasilan yang lebih baik daripada lingkungan di luar ruangan dalam mengidentifikasi golongan darah dari sampel darah kering. Jenis substrat terbaik yang dapat menyimpan darah pada waktu pemaparan hingga 336 jam (14 hari) adalah kain jenas denim kering, denim berlapis hitam, dan stretch denim.
\end{abstract}

Kata Kunci: golongan darah, dalam dan luar ruangan, jeans, absosrbsi-elusi 


\section{PENDAHULUAN}

Darah merupakan cairan tubuh yang dimiliki manusia untuk menjaga fungsi normal tubuh yang berperan dalam transportasi oksigen, bahan makanan maupun sisa metabolit serta mendistribusikan berbagai jenis hormon dan antibodi ke seluruh tubuh (Pearce 2012). Darah juga digunakan sebagai identitas atau ciri khusus dari seseorang melalui analisis golongan darah maupun profil DNA-nya, sehingga dapat diketahui pemilik dari darah tersebut. Karena hal ini darah dijadikan sebagai salah satu barang bukti biologis yang sangat penting dalam analisis forensik.

Pada umumnya tindak kejahatan seperti pembunuhan akan meninggalkan jejak noda darah di TKP baik darah milik korban maupun pelaku kejahatan (Castro \& Colye 2013). Darah biasanya ditemukan di pakaian korban maupun pelaku yang masih basah atau sudah kering sehingga penyidik dalam melakukan proses identifikasi perlu memastikan apakah darah tersebut merupakan darah manusia yang dapat diidentifikasi golongan darahnya (Idries \& Tjiptomartono 2011).

Golongan darah diklasifikasikan berdasarkan ada tidaknya antigen atau aglutinogen yang membentuk aglutinasi pada sel darah putih. Aglutinogen dibagi menjadi dua yaitu aglutinogen A dan B. Apabila ditemukan aglutinogen A maka golongan darah bertipe $\mathrm{A}$, apabila ditemukan aglutinogen $\mathrm{B}$ maka golongan darah bertipe $\mathrm{B}$, jika ditemukan aglutinogen $\mathrm{A}$ dan $\mathrm{B}$ maka golongan darah bertipe $\mathrm{AB}$, jika tidak ditemukan aglutinogen $\mathrm{A}$ dan $\mathrm{B}$ maka darah bertipe $\mathrm{O}$ (Guyton \& Hall 2016). Golongan darah dapat diuji dengan menguji interaksi antara antigen dengan antibodinya. Jika antigen (aglutinogen) sesuai dengan antibodi (aglutinin), maka akan terjadi ikatan pada sel darah merahnya. Menurut Suryo (2012), orang yang memiliki golongan darah A memiliki anti-B dalam serum atau plasmanya dan antigen A yang terdapat di permukaan sel eritrositnya. Orang yang memiliki golongan darah $\mathrm{B}$ memiliki anti-A dan antigen B. Jika antigen A bertemu dengan anti-A darah akan mengalami penggumpalan (aglutinasi) yang akan mengakibatkan kematian, sehingga orang yang memiliki tipe golongan darah $\mathrm{A}$ tidak dapat ditransfusikan kepada orang yang memiliki golongan darah $\mathrm{B}$.

\section{BAHAN DAN CARA KERJA}

Penelitian ini merupakan penelitian eksperimental dengan perlakuan berupa preparasi sampel kain jeans yang ditetesi darah hingga 336 jam (14 hari) dan dilatakkan di dalam dan luar ruangan yang dilakukan di Laboratorium Biologi Dasar dan Limbah, Fakultas Biologi, Universitas Kristen Satya Wacana, dan Laboratorium Forensik Cabang Semarang untuk melakukan identifikasi golongan darah. Penelitian dilakukan dari tanggal 15 Februari sampai 22 Maret 2021. Bahan yang digunakan antara lain suspensi darah A, B, dan $\mathrm{O}$, kain jeans stretch denim, jeans ramie denim, jeans denim kering, denim berlapis hitam, larutan $\mathrm{NaCl}$ 0,98\%, leucomalachite green (LMG) dan hidrogen peroksida, antisera A dan B dari merk Tulip Diagnostics, dan anti-H yang dibuat dari tumbukan kacang merah yang dihaluskan, akuades, kain kassa, dan kertas saring.

Tahap pertama dilakukan preparasi sampel menurut Instruksi Laboratorium Forensik Polri (2012) dengan cara mengambil darah dari lengan probandus sebanyak 12-14 cc kemudian diteteskan pada keempat substrat kain jeans sebanyak 1 tetes dan diratakan. Selanjutnya substrat diletakkan di luar dan dalam ruangan selama 264 jam (11 hari), 288 jam (12 hari), 312 jam (13 hari), dan 336 jam (14 hari). Kondisi lingkungan yang diamati meliputi suhu, intensitas cahaya, kelembaban, dan cuaca. Selanjutnya sampel darah yang telah diberi perlakuan kemudian dipindahkan ke kain kassa berukuran $2 \times 2 \mathrm{~cm}$ dengan cara kain kasa yang telah dibasahi larutan $\mathrm{NaCl}$ 0,98\% kemudian ditempel-tempelkan pada noda darah yang terdapat di substrat kain jeans hingga darah menempel pada kain kassa. Selanjutnya kain kassa dikering anginkan selama 24 jam pada suhu ruang dan dibungkus dengan kertas payung yang diberi silica gel untuk mengurangi kelembaban sampel.

Tahap kedua dilakukan pengujian awal untuk memastikan sampel adalah noda darah (Daeid \& Houck 2007) dengan cara sampel darah yang terdapat di kain kassa selanjutnya 
diurai dan beberapa helaiannya diambil kemudian dilatakkan pada kertas saring dan ditetesi dengan hidrogen peroksida dan leucomalachite green (LMG) sebanyak 2 tetes. Selanjutnya hasil diamati dengan melihat adanya perubahan warna menjadi hijau kebiruan jika hasil dinyatakan positif masih terdapat noda darah.

Tahap ketiga dilakukan pembuatan sel eritrosit darah pembanding (Instruksi Laboratorium Forensik Polri, 2012) dengan cara 3 tabung reaksi yang diberi label A, B, O ditambahkan larutan $\mathrm{NaCl} 0.98 \%$ sebanyak 50 tetes dan sampel darah A, B, O yang diambil dari ujung jari probandus yang diketahui golongan darahnya sebanyak 8 tetes. Kemudian sampel dihomogenkan dan disentrifugasi dengan kecepatan 1000 rpm selama 1 menit pada suhu ruang. Selanjutnya dilakukan pencucian dengan cara supernatan dari hasil sentrifugasi dibuang kemudian ditambahkan $\mathrm{NaCl}$ 0,98\% sebanyak 50 tetes dan disentrifugasi kembali. Tahapan pencucian dilakukan berulang sebanyak 5 kali. Hasil suspensi sel eritrosit paling akhir kemudian ditambahkan 50 tetes $\mathrm{NaCl}$ 0,98\% dan ditutup dengan plastic wrap kemudian disimpan dalam refrigerator bersuhu $4^{\circ} \mathrm{C}$ hingga waktu pemeriksaan golongan darah (48 jam).

Tahap keempat dilakukan pemeriksaan golongan darah dengan metode absorptionelution blood group test elution (Kind,1960) dengan cara sampel kain kassa yang telah diurai menjadi helaian benang selanjutnya dimasukan dalam tabung reaksi yang diberi label A, B, O sebanyak 7-10 helai dan ditambahkan antisera $\mathrm{A}$ untuk tabung uji $\mathrm{A}$, antisera B untuk tabung uji $\mathrm{B}$, dan anti-H untuk tabung $\mathrm{O}$ kemudian direndam dan dimasukkan ke dalam refrigerator selama 24 jam dengan suhu $4^{\circ} \mathrm{C}$. Proses ini bertujuan supaya antisera meresap ke dalam helaian benang. Proses selanjutnya dilakukan pencucian atau elution. Sampel dicuci dengan $\mathrm{NaCl}$ 0,98\% sebanyak 7 kali yang bertujuan untuk menghilangkan pengotor yang tidak terikat oleh antibodi dan antigen. Pencucian juga bertujuan untuk menghilangkan antisera berlebih. Selanjutnya sampel dimasukan ke dalam oven pada suhu $56^{\circ} \mathrm{C}$ selama 20 menit dengan tujuan untuk melepas ikatan antisera dan antibodi yang berikatan pada benang. Kemudian sampel didinginkan pada suhu ruang dan benang dalam tabung reaksi diambil dan dibuang. Tahap selanjutnya sampel ditambahkan suspensi eritrosit A, B,dan $O$ yang telah dibuat 2 hari sebelum pemeriksaan golongan darah dilakukan sebanyak 2-3 tetes sesuai dengan golongan darah yang diuji. Tabung kemudian didiamkan kurang lebih selama 10 menit dan disentrifugasi dengan kecepatan 1000 rpm selama 1 menit. Kemudian dilakukan pengamatan dengan cara tabung digoyangkan secara perlahan untuk melihat ada tidaknya aglutinasi yang terbentuk. Pengamatan dilaku-kan secara kualitatif. Apabila aglutinasi terjadi hanya pada tabung A maka sampel bergolongan darah A, jika aglutinasi terjadi hanya pada tabung $\mathrm{B}$ maka sampel bergolongan darah $B$, jika terjadi aglutinasi pada tabung $\mathrm{A}$ dan $\mathrm{B}$ maka sampel bergolongan darah $\mathrm{AB}$ dan jika sampel hanya terbentuk aglutinasi pada tabung $\mathrm{O}$ maka sampel bergolongan darah $\mathrm{O}$. Hasil yang telah didapat kemudian dicacat pada tabel pemeriksaan golongan darah.

\section{HASIL}

\section{Uji konfirmasi golongan darah}

Uji konfirmasi golongan darah digunakan golongan darah $\mathrm{O}$ yang diambil dari vena probandus, kemudian darah dilatakkan pada slide dan ditetesi antigen A, B, dan O. Hasil yang diperoleh dapat dilihat pada Gambar 1 dimana hasil yang didapat menunjukkan jenis golongan darah yang digunakan pada penelitian merupa-kan darah positif $(+)$ bergolongan darah $\mathrm{O}$. Hal ini diketahui dari terbentuknya aglutinasi pada darah yang ditetesi anti $\mathrm{H}$.

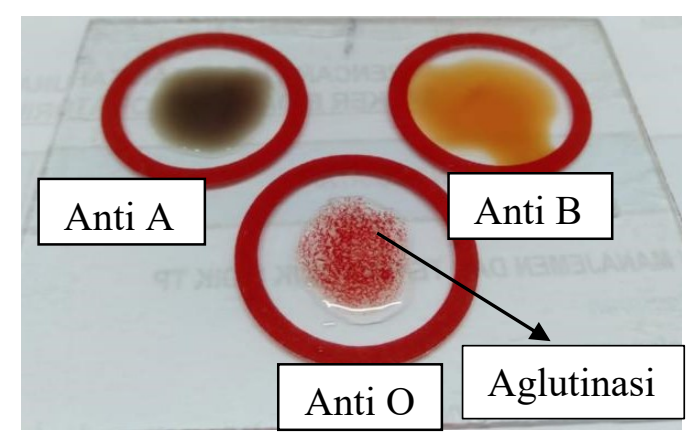

Gambar 1. Hasil uji konfirmasi darah aglutinasi pada golongan darah $\mathrm{O}$ 


\section{Uji presumtif kehadiran darah pada sampel darah kering}

Tabel 1 menunjukkan uji konfirmasi kehadiran darah pada sampel substrat kain jeans stretch denim, jeans ramie denim, jeans denim kering, denim berlapis hitam di dalama ruangan menunjukkan hasil yang positif. Sedangkan untuk semua sampel dari luar ruangan menunjukkan hasil negatif. Hasil positif ditandai dengan adanya perubahan warna pada sampel menjadi biru kehijauan saat ditetesi larutan hidrogen peroksida $\left(\mathrm{H}_{2} \mathrm{O}_{2}\right)$ dan leuco malachite green (LMG).

Tabel 1. Hasil uji Konfirmasi kehadiran darah pada sampel substrat kain jeans

\begin{tabular}{|c|c|c|c|c|c|}
\hline \multirow{2}{*}{$\begin{array}{c}\text { Substrat } \\
\text { kain jeans }\end{array}$} & \multirow{2}{*}{$\begin{array}{c}\text { Kondisi } \\
\text { lingkungan }\end{array}$} & \multirow{2}{*}{$\begin{array}{c}\text { Waktu } \\
\text { (jam) }\end{array}$} & \multicolumn{3}{|c|}{ Ulangan } \\
\hline & & & 1 & 2 & 3 \\
\hline \multirow{8}{*}{$\begin{array}{c}\text { Stretch } \\
\text { denim }\end{array}$} & & 264 & + & + & + \\
\hline & Dalam & 288 & + & + & + \\
\hline & ruangan & 312 & + & + & + \\
\hline & & 336 & + & \pm & + \\
\hline & & 264 & - & - & - \\
\hline & Luar & 288 & - & - & - \\
\hline & rauangan & 312 & - & - & - \\
\hline & & 336 & - & - & - \\
\hline \multirow{8}{*}{$\begin{array}{l}\text { Ramie } \\
\text { denim }\end{array}$} & & 264 & + & + & + \\
\hline & Dalam & 288 & + & + & + \\
\hline & ruangan & 312 & + & + & + \\
\hline & & 336 & + & + & + \\
\hline & & 264 & - & - & - \\
\hline & Luar & 288 & - & - & - \\
\hline & rauangan & 312 & - & - & - \\
\hline & & 336 & - & - & - \\
\hline \multirow{8}{*}{$\begin{array}{l}\text { Denim } \\
\text { Kering }\end{array}$} & & 264 & + & + & + \\
\hline & Dalam & 288 & + & + & + \\
\hline & ruangan & 312 & + & + & + \\
\hline & & 336 & + & + & + \\
\hline & & 264 & - & - & - \\
\hline & Luar & 288 & - & - & - \\
\hline & rauangan & 312 & - & - & - \\
\hline & & 336 & - & - & - \\
\hline \multirow{8}{*}{$\begin{array}{c}\text { Denim } \\
\text { berlapis } \\
\text { hitam }\end{array}$} & & 264 & + & + & + \\
\hline & Dalam & 288 & + & + & + \\
\hline & ruangan & 312 & + & + & + \\
\hline & & 336 & + & + & + \\
\hline & & 264 & - & - & - \\
\hline & Luar & 288 & - & - & - \\
\hline & rauangan & 312 & - & - & - \\
\hline & & 336 & - & - & - \\
\hline
\end{tabular}

Identifikasi golongan darah sistem ABO sampel darah kering di dalam dan luar ruangan

Gambar 2 menunjukkan hasil identifikasi golongan darah pada substrat kain jeans stretch denim, jeans ramie denim, jeans denim kering, denim berlapis hitam pada kondisi dalam ruangan perlakuan 264, 288, 312, dan 336 jam. Dimana semua sampel berhasil diidentifikasi dan dinyatakan sampel bergolongan darah dengan tipe $\mathrm{O}$, hal ini dinyatakan positif karena terbentuknya penggumpalan atau aglutinasi pada sampel darah tersebut. Dari keempat substrat kain jeans yang dipapari darah dan diletakkan dalam kondisi dalam ruangan hingga 336 jam menunjukkan hasil positif dengan presentase keberhasilan identifi-kasi hingga 100\% sedangkan di luar ruangan persentase keberhasilan identifikasi dari ke-empat jenis substrat kain jeans adalah $0 \%$ yang ditunjukan oleh Tabel 2.

\section{Karakteristik Sampel Darah Kering pada Permukaan Kain Jeans}

Gambar 3 menunjukkan karakteristik keempat substrat kain jeans yang digunakan. Substrat kain jeans memiliki permukaan tekstur
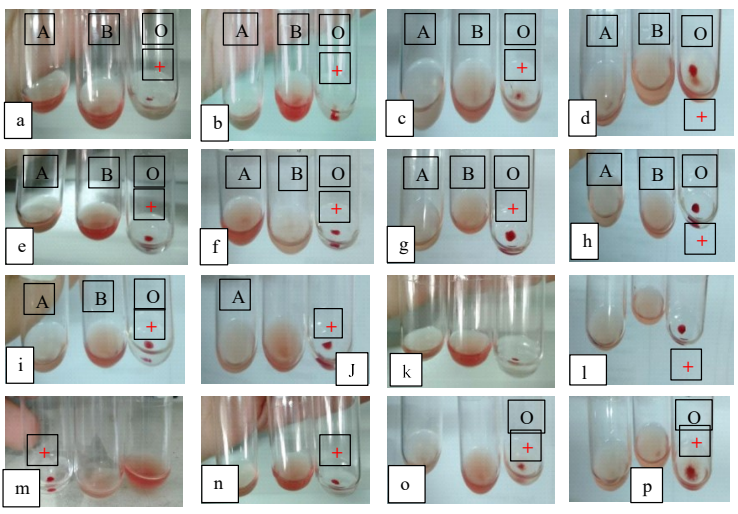

Gambar 2. Hasil identifikasi golongan darah pada substrat kain jeans di didalam ruangan

Keterangan: (a) ramie denim perlakuan 264 jam (b) ramie denim perlakuan 288 jam (c) ramie denim perlakuan 312 jam (d) ramie denim perlakuan 336 jam (e) stretch denim perlakuan 264 jam (f) stretch denim perlakuan 288 jam (g) stretch denim perlakuan 312 jam (h) stretch denim perlakuan 336 jam (i) denim berlapis hitam perlakuan 264 jam (j) denim berlapis hitam perlakuan 288 (k), denim berlapis hitam perlakuan 312 jam (l) denim berlapis hitam perlakuan 336 jam (m) denim kering perlakuan 264 jam (n) denim kering perlakuan 288 jam (o) denim kering perlakuan 312 jam (p) denim kering perlakuan 336 jam. 
serat yang berbeda-beda hal ini dapat mempengaruhi proses penyerapan darah serta mengetahui apakah darah dapat tersimpan di sela-sela permukaan kain, benang, ataupun tenunan kain jeans. Stretch denim memiliki karakteristik berwarna hitam, halus dan lentur yang tersusun dari jenis bahan katun, denim dan serat elastis (spandex). Ramie denim memiliki tekstur kain halus, berwarna navy dan tersusun dari serat rami, katun, polyester serta denim. Karakteristik dari denim kering yaitu berwarna biru dongker, memiliki tektur kain yang keras, kasar dan kaku. Denim kering tersusun atas bahan katun dan denim. Sedangkan karakteristik dari denim berlapis hitam dengan tektur permukaan bahan halus dan mengkilap yang tersusun dari bahan katun dan akrilik.

Tabel 2. Persentase keberhasilan identifikasi golongan darah pada substrat kain jeans lingkungan dalan dan luar rumah.

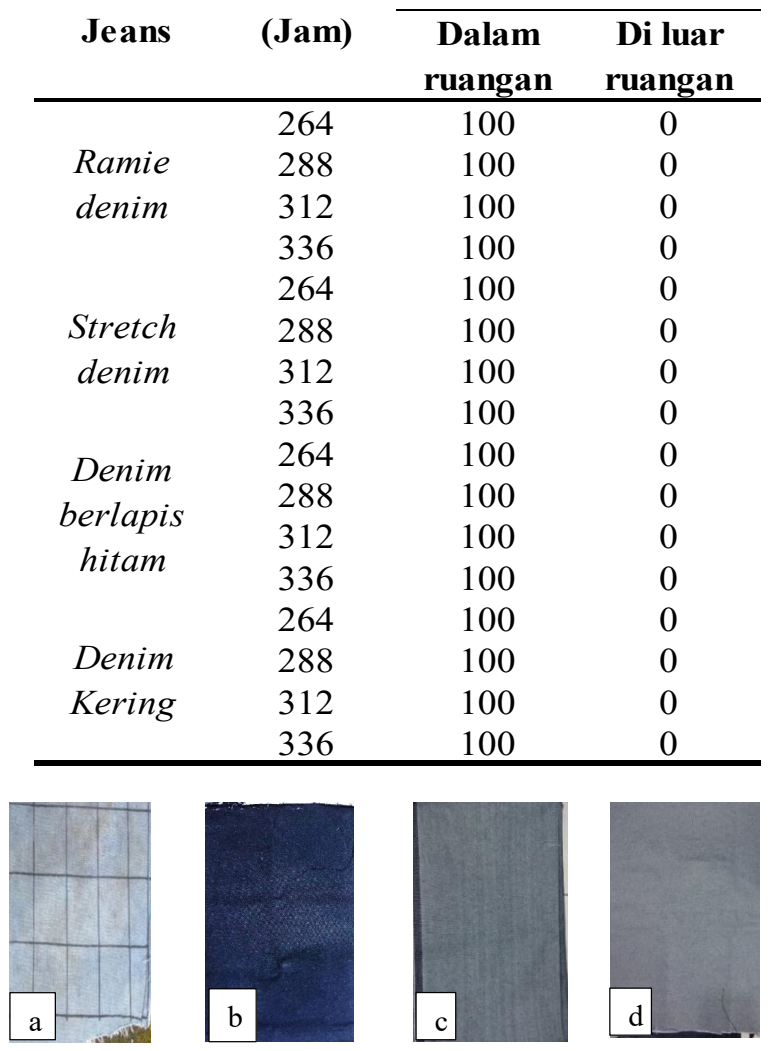

Gambar 3. Substrat kain jeans yang digunakan dalam penelitian

Keterangan: (a) Ramie denim, (b) Stretch denim, (c) denim berlapis hitam, (d) denim kering.

\section{Pengaruh Variasi Waktu pada Lingkungan Terhadap Sampel Darah Kering di Substrat Kain Jeans}

Hasil yang didapatkan yaitu pengukuran suhu, kelembaban udara, intensitas cahaya, dan pengamatan cuaca didalam dan luar ruangan ditunjukan oleh Table 3. Suhu tertinggi mencapai $27,9^{\circ} \mathrm{C}$ dan paling rendah mencapai $22,8^{\circ} \mathrm{C}$. Kelembaban udara tertinggi mencapa $99 \%$ dan terendah mencapai $73 \%$. Intensitas cahaya paling tinggi mencapai 360 lux dan paling rendah mencapai 10 lux. Hasil pengukuran yang dilakukan di dalam ruangan lebih terkontrol karena tidak mengalami kontak langsung dengan hujan dan panas yang dapat memicu naik dan turunnya suhu lingkungan serta kelembaban udara. Terkontrolnya kondisi lingkungan ini mempengaruhi kemungkinan sampel darah pada substrat kain jeans tersimpan lebih baik. Sedangkan hasil dari pengukuran kondisi di luar ruangan suhu tertinggi mencapai $29,1^{\circ} \mathrm{C}$ dan paling rendah mencapai $21^{\circ} \mathrm{C}$. Pada pengamatan kelembaban udara nilai paling tinggi mencapai $98 \%$ dan terendah dengan nilai $70 \%$. Nilai tertinggi dari intensitas cahaya mencapai 16000 lux dan terendah mencapai 10 lux. Selama proses perlakuan berlangsung, sampel mengalami paparan hujan sebanyak 9 kali dan total terpapar hujan kurang lebih sebanyak 13 jam yang terjadi pada hari ke-1, ke -2, ke-3, ke-4, ke-6, ke-11, ke-13, dan ke-14. Paparan paling lama adalah 6 jam dengan intensitas hujan tinggi di hari ke-1 pukul 12.0018.00 WIB. (Tabel 3)

\section{PEMBAHASAN}

\section{Uji Konfirmasi Golongan Darah}

Dalam uji konfirmasi digunakan metode slide dimana prinsip dasar dari metode ini yaitu ketika sel darah mengandung antigen yang sesuai dengan antibodi yang terdapat di dalam reagen antisera, maka akan membentuk ikatan yang ditandai dengan munculnya aglutinasi (Khoodijah\& Qomariyah 2019). Aglutinasi terjadi karena adanya reaksi antigen dan antibodi yang sejenis. Dalam pemeriksaan golongan darah, jika golongan darah A ditambahkan reagen anti-A akan mengalami aglutinasi, pada golongan darah B akan mengalami aglutinasi jika ditambahkan 
anti-B, begitu juga pada golongan darah $\mathrm{AB}$ akan mengalami aglutinasi atau penggumpalan darah jika ditambahkan reagen anti-A dan anti-
B. Dan golongan darah O tidak akan menggumpal jika darah ditambahkan anti-A maupun anti-B (Hoffbrand et al. 2006).

Table 3. Hasil pengamatan dan pengukuran kondisi lingkungan di dalam dan luar ruangan

\begin{tabular}{|c|c|c|c|c|c|c|c|c|}
\hline \multirow{3}{*}{ Jam ke- } & \multirow{3}{*}{$\begin{array}{l}\text { Waktu } \\
\text { (jam) }\end{array}$} & \multicolumn{7}{|c|}{ Lingkungan } \\
\hline & & \multicolumn{3}{|c|}{ Dalam ruangan } & \multicolumn{4}{|c|}{ Luar ruangan } \\
\hline & & Suhu $\left({ }^{\circ} \mathrm{C}\right)$ & Kelembaban (\%) & IC (Lux) & Suhu $\left({ }^{\circ} \mathrm{C}\right)$ & Kelembaban (\%) & IC (Lux) & Cuaca \\
\hline \multirow[t]{3}{*}{0} & 12.00 & 25,9 & 89 & 30 & 26,6 & 90 & 4090 & $\begin{array}{l}\text { Hujan deras pukul } \\
\text { 12:00-18:00 }\end{array}$ \\
\hline & 18.00 & 24,1 & 90 & 40 & 25,5 & 88 & 20 & $\begin{array}{l}\text { Hujan deras pukul } \\
18 ; 00-20: 23\end{array}$ \\
\hline & 06.00 & 23,0 & 99 & 40 & 21,0 & 93 & 2010 & Berawan \\
\hline \multirow[t]{3}{*}{24} & 12.00 & 24,7 & 93 & 80 & 25,2 & 95 & 1530 & $\begin{array}{l}\text { Hujan deras pukul } \\
12: 00-17: 25\end{array}$ \\
\hline & 18.00 & 24,3 & 91 & 30 & 24,7 & 90 & 20 & Berawan mendung \\
\hline & 06.00 & 22,8 & 91 & 50 & 22,8 & 91 & 1640 & Berawan \\
\hline \multirow[t]{3}{*}{48} & 12.00 & 26,5 & 77 & 140 & 27,2 & 80 & 2270 & Grimis \\
\hline & 18.00 & 25,0 & 79 & 20 & 26,0 & 80 & 180 & Grimis \\
\hline & 06.00 & 23,1 & 88 & 20 & 23,8 & 98 & 630 & Berawan \\
\hline \multirow[t]{3}{*}{72} & 12.00 & 24,8 & 80 & 200 & 25,7 & 83 & 9200 & Berawan \\
\hline & 18.00 & 24,4 & 82 & 10 & 25,0 & 83 & 250 & Mendung \\
\hline & 06.00 & 23,1 & 91 & 50 & 23,5 & 92 & 1690 & Cerah berawan \\
\hline \multirow[t]{3}{*}{96} & 12.00 & 27,1 & 77 & 360 & 27,8 & 79 & 1120 & Cerah \\
\hline & 18.00 & 27,0 & 76 & 10 & 24,0 & 82 & 270 & Mendung \\
\hline & 06.00 & 23,0 & 89 & 30 & 23,5 & 90 & 450 & Berawan \\
\hline \multirow[t]{3}{*}{120} & 12.00 & 27,5 & 79 & 350 & 29,1 & 87 & 16000 & Cerah berawan \\
\hline & 18.00 & 25,6 & 88 & 20 & 25,6 & 88 & 250 & Grimis kecil \\
\hline & 06.00 & 24,0 & 82 & 30 & 24,1 & 83 & 490 & Berawan \\
\hline \multirow[t]{3}{*}{144} & 12.00 & 27,4 & 77 & 330 & 28,0 & 75 & 8400 & Cerah \\
\hline & 18.00 & 26,3 & 80 & 20 & 26,8 & 81 & 310 & Berawan \\
\hline & 06.00 & 24,4 & 78 & 20 & 25,3 & 81 & 260 & Berawan \\
\hline \multirow[t]{3}{*}{168} & 12.00 & 27,7 & 76 & 320 & 28,5 & 71 & 1400 & Cerah berawan \\
\hline & 18.00 & 26,2 & 73 & 10 & 25,2 & 74 & 20 & Berawan \\
\hline & 06.00 & 24,4 & 80 & 10 & 24,6 & 82 & 120 & Mendung \\
\hline \multirow[t]{3}{*}{192} & 12.00 & 27,9 & 73 & 260 & 28,1 & 71 & 6470 & Cerah \\
\hline & 18.00 & 26,3 & 75 & 10 & 25,3 & 89 & 50 & Mendung \\
\hline & 06.00 & 24,3 & 81 & 20 & 25,1 & 84 & 10 & Mendung \\
\hline \multirow[t]{3}{*}{216} & 12.00 & 26,0 & 73 & 250 & 27,0 & 70 & 6380 & Cerah \\
\hline & 18.00 & 26,0 & 73 & 20 & 23,0 & 78 & 180 & Berawan \\
\hline & 06.00 & 24,0 & 76 & 10 & 23,2 & 86 & 130 & Mendung \\
\hline \multirow[t]{3}{*}{240} & 12.00 & 26,2 & 77 & 120 & 24,7 & 93 & 1240 & Berawan \\
\hline & 18.00 & 25,0 & 78 & 20 & 25,0 & 83 & 170 & Berawan \\
\hline & 06.00 & 24,1 & 80 & 10 & 23,3 & 81 & 100 & $\begin{array}{l}\text { Hujan deras pukul } \\
\text { 06:00-08:05 }\end{array}$ \\
\hline \multirow[t]{3}{*}{264} & 12.00 & 25,0 & 84 & 330 & 26,0 & 86 & 10200 & Berawan \\
\hline & 18.00 & 25,0 & 75 & 10 & 25,0 & 74 & 20 & Mendung \\
\hline & 06.00 & 24,0 & 82 & 20 & 24,0 & 82 & 120 & Mendung \\
\hline \multirow[t]{3}{*}{288} & 12.00 & 25,3 & 80 & 190 & 26,0 & 89 & 270 & $\begin{array}{l}\text { Hujan sedang } \\
\text { pukul 12:00-14:45 }\end{array}$ \\
\hline & 18.00 & 25,0 & 81 & 20 & 24,8 & 85 & 30 & Berawan \\
\hline & 06.00 & 24,3 & 80 & 20 & 24,2 & 84 & 20 & Berawan \\
\hline \multirow[t]{3}{*}{312} & 12.00 & 27,4 & 76 & 360 & 28 & 81 & 11800 & Cerah \\
\hline & 18.00 & 26,0 & 90 & 240 & 26,1 & 90 & 30 & $\begin{array}{l}\text { Hujan ringan pukul } \\
\text { 18:00-20:52 }\end{array}$ \\
\hline & 06.00 & 23,0 & 85 & 10 & 24 & 81 & 110 & Berawan \\
\hline \multirow[t]{2}{*}{336} & 12.00 & 26,0 & 73 & 240 & 26 & 86 & 250 & Mendung \\
\hline & 18.00 & 25,2 & 75 & 20 & 25 & 74 & 20 & Berawan \\
\hline
\end{tabular}




\section{Uji Presumtif Konfirmasi Kehadiran Darah pada Sampel Darah Kering}

Dalam uji presumtif, jumlah darah yang terdapat pada sampel uji mempengarui kepekatan warna hijau yang dihasilkan pada sampel yang positif darah pada saat ditetesi leucomalachite green (LMG) dan hidrogen peroksida (Andersoon, 2017). Dalam uji peroksidase dibutuhkan reagen lain, hal ini dikarenakan leucomalachite green bukan termasuk dalam uji peroksidase sehingga diperlukan reagen lain seperti hydrogen peroxide. Menurut (Soderquist et al. 2012), ketika hydrogen peroxide ditambahkan pada sampel yang mengandung darah, maka akan terjadi reaksi teroksidasi dimana hemoglobin memiliki sifat seperti peroksida yang mengkatalis pemecahan hidrogen perosida dan menunjukkan adanya zat besi $\left(\mathrm{Fe}^{2+}\right)$ pada darah serta mengkatalis produksi radikal hidroksi $\left({ }^{*} \mathrm{OH}\right)$ dan akan menimbulkan reaksi yang ditandai dengan adanya perubahan warna. Reaksi kandungan zat besi pada darah dengan hydrogen peroxide dapat digambarkan sebagai berikut:

$$
\mathrm{Fe}^{2+}+\mathrm{H}_{2} \mathrm{O}_{2} \longrightarrow \mathrm{Fe}^{3+}+* \mathrm{OH}+\mathrm{OH}^{-}
$$

(Baynes \& Dominiczak, 2014).

\section{Hasil Identifikasi Golongan Darah Sistem ABO Sampel Darah Kering di dalam dan luar ruangan.}

Dalam pengujian golongan darah dapat menggunakan noda darah kering, karena sampel darah yang di identifikasi dengan metode absorpsi-elusi dilakukan dengan mendeteksi ada tidaknya antigen dalam darah tersebut. Prinsip kerja dari metode absorpsi-elusi yaitu menguji sensitifitas antigen pada sampel dengan cara mengikat antigen pada sampel yang diduga darah sehingga membentuk aglutinasi atau gumpalan serta berbanding lurus dengan jumlah antibodi yang terikat pada sampel ketika proses absopsi berlangsung. Menurut Mozayani (2006), dalam suhu rendah proses absopsi akan berlangsung dengan cara antigen akan berikatan dengan antiodi, sehingga sampel perlu diinkubasi dalam lemari pendingin dengan suhu $4^{\circ} \mathrm{C}$. Sedangkan proses elusi akan berlangsung ketika dilakukan pemanasan yang bertujuan untuk memindahan ikatan antibodi-antigen yang terdapat di dalam matriks darah supaya berpindah ke larutan saline (Day 2002) Munculnya hasil negatif pada sampel darah pdi luar ruangan dapat diakibatkan oleh beberapa kemungkinan, salah satunya yaitu kehadiran darah dalam kuantitas rendah, hal tersebut ditunjukan dengan uji presumtif dimana hasil uji di luar ruangan menunjukkan warna yang lebih pudar dibandingkan dengan kondisi di dalam ruangan.

\section{Karakteristik Sampel Darah Kering pada Permukaan Kain Jeans}

Jenis denim memiliki tipe tenunan yang berbeda-beda dan membuat penyerapan serta daya simpan darah yang berbeda pula. Kain jeans merupakan kain yang tersusun dari benang lusi (benang tenun yang disusun sejajar memanjang dan terikat di kedua ujungnya) putih atau berwarna yang biasanya terbuat dari kapas seperti corded atau benang combed, yang berasal dari bahan katun. Namun ada beberapa jenis kain jeans yang menggunakan bahan campuran seperti rayon, lycra, dan polyester sesuai dengan kegunaannya (Nathanael 2013). Denim kering merupakan jenis jeans yang memiliki tekstur permukaan lebih keras dan kaku dibandingkan dengan jenis jeans yang lain. Ramie denim merupakan jenis jeans yang bahan denimnya dicampur dengan serat tanaman rami yang membuat bahan ini lebih halus, tidak berkerut, tidak mudah kotor dan tidak mudah menyerap air karena memiliki struktur permukaan yang kurang berpori dan ketat (Verdon et al. 2013). Karena tidak adanya celah antar benang mengakibatkan darah tidak mudah menyerap dan tidak mengendap kelapisan serat. Stretch denim merupakan jenis jeans yang memiliki tekstur elastis dan lentur karena dalam pembuatannya dicampur dengan bahan elastis yaitu spandex. Bahan spandex adalah serat buatan yang elastis dan memiliki daya serap yang kurang baik, karena membuat uap air terperangkap dan tidak dapat ditransfer keluar (Widjaja dkk. 2018). Menurut (Kara 2018), stretch denim memiliki jenis tenun silang kepar atau twill weave yang karakteristik kainnya memiliki garis diagonal sehingga membuat darah mudah mengendap dalam serat kain. Denim berlapis hitam adalah jenis jeans yang mengandung bahan acrylic, dimana bahan acrylic memiliki sifat yang mampu mengawetkan 
kain jeans agar lebih tahan lama digunakan. Jika kain jeans jenis ini terkena gesekan maka akan membuat efek mengkilap pada kain jeans (Rahma 2018).

\section{Pengaruh Variasi Waktu pada Lingkungan Terhadap Sampel Darah Kering di Substrat Kain Jeans}

Kondisi fisik sampel darah pada substrat kain jeans pada kondisi di luar ruangan dan didalam ruangan memiliki perbedaan yang sangat jelas. Kondisi fisik sampel lingkungan di dalam ruangan menunjukkan bahwa noda darah masih terlihat jelas hingga pengamatan jam ke 336 , sedangkan pada kondisi di luar ruangan sampel darah sudah pudar dan hilang dari hari pertama pengamatan. Hal ini terjadi karena adanya pengaruh curah hujan yang terdapat di luar ruangan sehingga mengakibatkan darah yang tersimpan pada substrat kain menjadi encer dan terbawa aliran air hujan. Karena hal ini kemungkinan darah yang terdapat pada substrat kain jeans menjadi tidak ada. Intensitas cahaya dan suhu juga dapat mempengaruhi penyimpanan bercak darah karena lingkungan yang memiliki kelembaban yang tinggi akan mempercepat oksidasi sampel darah (Bremmer et al. 2011). Menurut (Alaeddini et al. 2010), material biologis seperti darah, jaringan epitel, dan jaringan ikat sangat mudah terdegradasi di lingkungan yang memiliki paparan panas tinggi dan kelembaban yang tinggi. Selain itu paparan panas matahari mengakibatkan sampel menjadi rusak. Menurut Chiu et al. (1997) sel darah dapat mengalami kerusakan ketika terkena paparan lingkungan, salah satu penyebab kerusakan darah oleh lingkungan yaitu karena terjadi proses oksidasi. Proses oksidasi terjadi akibat adanya interaksi darah dengan udara sekitar sehingga menyebabkan terjadinya deformasi pada struktur sel darah dan sel darah mengalami denaturasi hemoglobin. Denaturasi hemoglobin yang terjadi tersebut mengakibatkan sel darah sulit diidentifikasi karena sel darah merah kemungkinan mengalami lisis akibat dari air hujan.

\section{KESIMPULAN}

Dari penelitian ini dapat disimpulkan bahwa pada waktu papar 366 jam di dalam ruangan masih dapat dilakukan identifikasi dengan baik, sedangkan waktu papar 264 jam untuk sampel darah kering di luar ruangan sudah tidak dapat dilakukan identifikasi. Lingkungan di dalam ruangan memberikan persentase keberhasilan lebih baik dibandingan di luar lingkungandalam mengidentifikasi golongan darah dari sampel darah kering. Jenis substrat kain jeans dengan waktu perlakuan tidak berpengaruh terhadap keberhasilan identifikasi golongan darah.

\section{UCAPAN TERIMAKASIH}

Ucapan terima kasih kepada semua pihak yang telah mendukung terlaksananya penelitian ini yaitu dosen pembimbing dan laboran, Fakultas Biologi, Universitas Kristen Satya Wacana dan Laboratorium Forensik Cabang Semarang yang telah memberikan kesempatan sehingga penelitian dapat terlaksana dan pihakpihak lain yang berkontribusi dalam penelitian.

\section{KONTRIBUSI PENULIS}

YTU. Berkontribusi sebagai penulis utama dan dalam analisis naskah ini dengan dibantu oleh SPH dan BN sekaligus sebagai pembimbing dan pengarah dalam penulisan naskah.

\section{DAFTAR PUSTAKA}

Alaeddini, R., SJ. Walsh \& A. Abbas. 2010. Forensic science international: genetics forensic implications of genetic analyses from degraded DNA-a review. Forensic Science International: genetics 4:148-157 Andersoon, R. 2017. An Evaluation of Two Presumptive Blood Tests and Three Methods to Visualise Blood. Independent Thesis. Swedia: Departement of Physics, Chemistry and Biologi Linkoping University.

Baynes, JW., \& MH. Dominiczk. 2014. Medical Biochemistry. 4th ed Endinburgh. Philadelphia: Elsevier, 214-235.

Bremmer, RH., KG. Briun, MJC. Gemert TG. Leeuwen, \& MC. Aalders. 2011. Forensic quest for age determination of bloodstains. Netherlands; Forensic Science International. 216 (1): 1-9.

Castro, DM \& HM. Coyle. 2013. Biological 
Evidence Collection and Forensic Blood Identification. USA: University of New Haven. 2-11.

Chiu, DTY., \& TZ. Liu. 1997. Free Radical and Oxidative Damage in Human Blood Cells. Biomedical Science. 4: 256-259.

Daeid, NN. \& MM. Houck. 2007. Interpol's Forensic Science Review. HandBook. Florida: CRC Press. pp. 48-55.

Day, RA., \& AL. Underwood. 2002. Analisis Kimia Kuantitatif. Jakarta: Erlangga. 396404.

Guyton, AC., \& JE. Hall. 2016. Textbook of Medical Physiology. Thirteenth ed. Mississipi: ELSEVIER. Pp. 1022

Hoffbrand, AV., PAH. Moss, \& JE. Pettit. 2006. Essential Haematology (Fifth Edit). Blackwell Publishing. 221-295.

Idries, AM., \& AL. Tjiptomartono. 2011. Penerapan Ilmu Kedokteran Forensik dalam Proses Penyidikan Edisi Revisi. Jakarta : CV. Agung Seto. 50-203.

Instruksi Kerja Laboratorium Forensik Polri dipublikasi oleh Sub bagian manejemen mutu tahun 2012. Puslabfor Jakarta. pp. 12.

Khoodijah, NM., \& N. Qomariyah. 2019. Derajat Aglutinasi Pemeriksaan Golongan Darah Metode Cell Grouping Berdasarkan Tingkat Konsnetrasi Suspensi Sel. Jurnal Jaringan Laboratorium Medis. 1 (1): 27-33.

Kara, G. \& M. Akgun. 2018. Effect of Weft Yarn Fiber Contents on the Moisture Management Performance of Denim Fabrics Woven whit Different Constructional Para-meters. Tekstil ve Konfeksion, 28(2): 151-161.

Kind, SS. 1960. Absorption-Elution Grouping of Dried Blood Smears. Nature. 185 (4710): 397-398.
Mozanyani, A., \& Noziglia. 2006. The forensic laboratory handbook. New Jersey: Humana press, Inc. pp. 5.

Nathanael, D. 2013. Eksplorasi Denim dengan Teknik Destruktif. Jurnal Tingkat Sarjana Seni Rupa dan Desain. 1 (2): 1-8.

Pearce, E. 2012. Anatomi dan Fisiologi untuk Paramedis. Jakarta: PT Gramedika. pp. 141-142.

Rahma, AI., \& A. Hermawan. 2018. Eksplorasi shibori pada material denim dengan pelunturan warna untuk produk fesyen. Eproceeding of art \& design. 5 (03): 22542266.

Soderquist, TJ., OM. Chesniak, MR. Witt, A. Paramo, VA. Keeling, \& JJ. Keleher. 2012. Evaluation of The Catalytic Decomposition of H2O2 Through Use of Organo-Metalic Complexes - A Potential Link to The Luminol Presumptive Blood Test. Forensic Science International. 219: 101-105.

Suryo. 2012. Genetika. Yogyakarta: Gadjah Mada University Press. 368-372.

Verdon, TJ., RJ. Mitchell, \& RAH. van Oorschot. 2013. The Influence of Substrate on DNA Transfer and Extraction Efficiency. Forensic Scince Internasional: Genetics.7: 167-175.

Widjaja, A., FJ. Thendean, J. Halim, C. Putri, C., IMB. Dwi, \& DLP. Suardama. 2018. Metode Pengembangan Produk Kreatif Bahan Dasar Goni dan Jeans yang Bernilai Ekonomis. Konvergensi Keilmuan Seni Rupa dan Desain Era 4.0. 20 (1): 6566. 
